\title{
Chapter 11 \\ Agricultural Market Intervention \\ and Emerging States in Africa
}

Masayoshi Honma

\subsection{Introduction}

Agricultural policies used to be regarded as determined by political institutions peculiar to each country. However, broad international comparisons of agricultural policy and economic performance reveal several common patterns. One is that countries tend to impose negative policies (taxation) on agriculture in the early stage of economic development while adopting positive policies (protection) for agriculture as the economy develops.

In the early stages of economic development, agriculture is the biggest industry and employs a large workforce. If economic development is promoted, as PettyClark's Law says, the agricultural sector shrinks in relative terms and the agricultural labor force also decreases. Taxation is imposed on agriculture despite the fact that it is the biggest industry with many workers. On the other hand, when development progresses, the agricultural sector is protected despite the fact that it shrinks. This phenomenon is called the "developmental paradox" (De Gorter and Swinnen 2002).

Starting in the 1980s, various models have been proposed to explain agricultural protection levels. ${ }^{1}$ Furthermore, extensive research has been conducted to enable international comparison of protection levels as well as analysis of the domestic political economy of agricultural protection and international trade policies. There has been a rich accumulation of data in this area. ${ }^{2}$

\footnotetext{
${ }^{1}$ See e.g. Anderson et al. (1986), Honma and Hayami (1986), Gardner (1987), Krueger et al. (1988, 1991), Bates (1989), Tracy (1989), Lindert (1991), Swinnen et al. (2001), and Anderson (2009).

${ }^{2}$ Also, there have been important developments on political economy in the economics profession. See e.g. Grossman and Helpman (1994, 2002), Shleifer (1997), Persson and Tabellini (2000), and Acemoglu et al. (2001).

M. Honma (西)

Department of Economics, Division of International Economics, Seinan Gakuin University, Fukuoka, Japan

e-mail: m-honma@seinan-gu.ac.jp

(C) The Author(s) 2019

K. Otsuka and K. Sugihara (eds.), Paths to the Emerging State in Asia and Africa,

Emerging-Economy State and International Policy Studies,

https://doi.org/10.1007/978-981-13-3131-2_11
} 
The agricultural policies of African countries have been analyzed quantitatively in a World Bank project published as a single volume (Anderson and Masters 2009). There are also a couple of comprehensive studies on the political economy of intervention in African agricultural trade (e.g. Bates and Block 2010). ${ }^{3}$ However, there remains considerable scope to explore the determinants of agricultural policy in Africa.

The "developmental paradox" arises when politicians seek to maximize their votes in the political market. The outcome is far from optimal from an economic viewpoint and presents an obstacle to agricultural development. Correcting this paradox is indispensable for economic growth. The purpose of this chapter is to clarify whether the "developmental paradox" applies to African agricultural policy and to discuss the proper strategy of economic growth for Africa's emerging economies.

\subsection{Distortion of Agricultural Markets in Africa}

Many agricultural policies intervene in the market, pushing down or pushing up the prices of agricultural products, which causes distortion in agricultural markets. The greatest distortion is caused by import duties and export taxes imposed by governments at the border. Border measures have the effect of isolating the domestic market from the international market and thus weaken the influence of changes in the international market. Therefore, the difference between the domestic and international prices of agricultural products is an indicator of how much the market is distorted.

Various studies have been conducted to measure agricultural protection levels. The most comprehensive is the National and Global Estimates of Distortions to Agricultural Incentives 1955-2011 by the World Bank. It measures agricultural protection levels in 75 countries over more than 50 years and creates protection indices not only for distortions by border measures but also by domestic measures such as subsidies and assistance in non-agricultural sectors.

What was observed was that, as expected, agricultural protection levels varied depending on the stage of economic development. Agriculture was taxed in the early stages of development, but as the economy developed, agriculture became subject to protection. This trend was also found in African countries. However, it was not as readily apparent as in rapidly industrializing East Asian countries, especially in those African countries where economic development remained low (Anderson and Masters 2009).

An important indicator showing the level of protection is the nominal rate of assistance (NRA). The NRA is defined as the percentage by which government policies have raised gross returns to farmers above what they would be without government intervention (or have lowered them, if the NRA is negative). The NRA is measured for individual agricultural products. In addition, in order to estimate the country level of protection, a weighted average of the NRA of individual agricultural

\footnotetext{
${ }^{3}$ See also Block and Bates (2011), Hoeffler (2011), and Poulton (2014).
} 


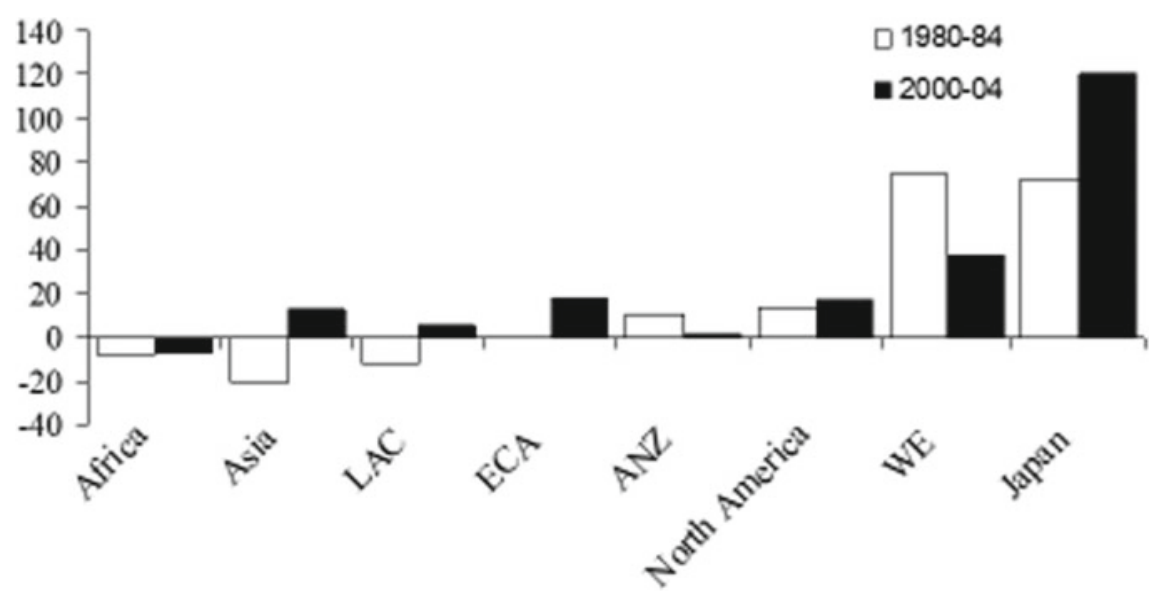

Fig. 11.1 Nominal rates of assistance to agriculture, by regions, 1980-84 and 2000-04 (percent). Source Anderson (ed.) (2009). Note LAC is Latin America and Caribbean, ECA is Europe and Central Asia, ANZ is Australia and New Zealand, and WE is Western Europe

products is calculated with weights of gross values of production at unassisted prices. Furthermore, the NRA by region is obtained as a weighted average of the NRA for each country in the region.

Figure 11.1 shows the NRA by region for the two periods of 1980-84 and 2000-04. Among developed country regions, the NRA of Western Europe (WE) and Japan are high, indicating that agricultural protection is prevalent. In fact, the figures show that Japan increased its protection level between the two periods while Western Europe's agricultural protection level was on a downward trend. Other developed region$\mathrm{s}$ - North America and Oceania (ANZ) — which are agricultural exporting areas, show low levels of agricultural protection.

On the other hand, in developing country regions, the NRA was negative in 1980-84, indicating that agriculture was taxed. Asia, which was heavily taxed in 1980-84, however, turned to positive in 2000-04, revealing a switch to agricultural protection. Africa was only the region where agricultural taxation remained in 2000-2004, indicating that it was impeding agricultural development.

Using NRA data in the World Bank database, Fig. 11.2 shows trends in Africa's NRA from 1955 to 2010 along with trends in Asia. Together with Asia, Africa shows negative values until the mid-1980s, indicating that the agricultural sector had been suppressed more than the international market price. However, the degree was lighter than in Asia. Asia was in the range of -20 to $-30 \%$, whereas in Africa it was in the -10 to $-20 \%$ in range. Agricultural policies in Asia also turned to positive values, i.e. protection policy, in the late 1980s. On the other hand, domestic prices of agricultural products in Africa were still lower than international prices even in later years. In both areas, the level of agricultural protection in recent years has fluctuated greatly 


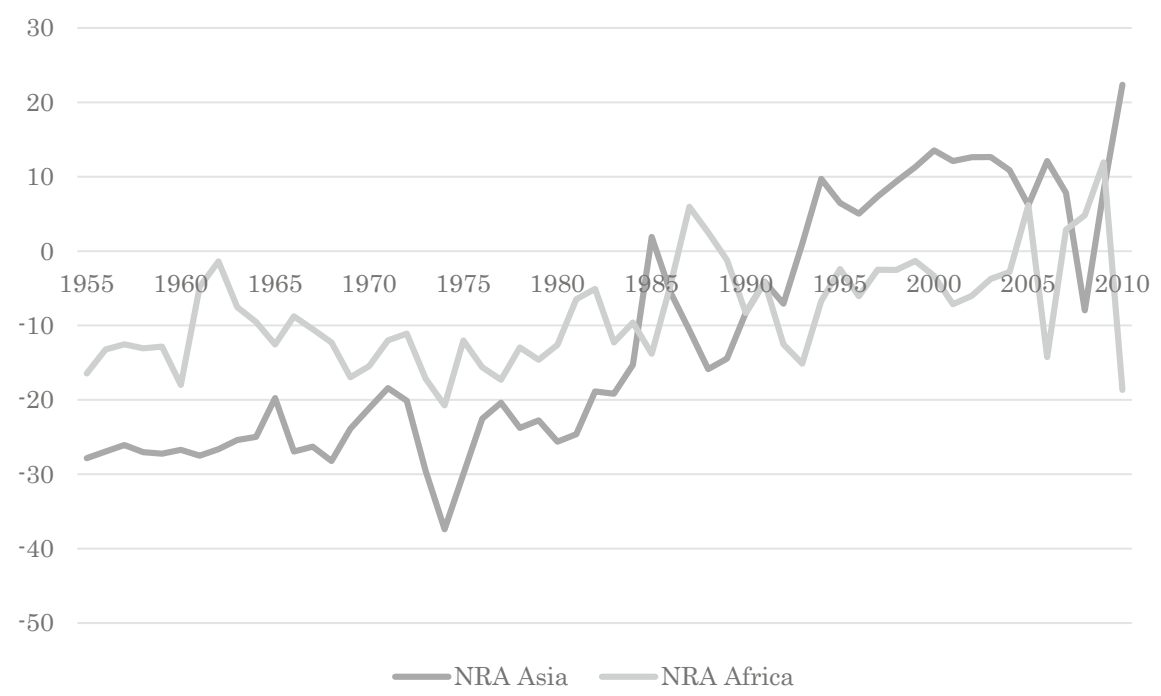

Fig. 11.2 Nominal rate of assistance (NRA) in Africa and Asia, 1955-2010. Source World Bank, National and Global Estimates of Distortions to Agricultural Incentives 1955-2011

from year to year, but looking at the overall trend for the past 50 years, it is clear that agricultural deprivation policy weakened and gradually switched to protection.

The overall trend in the weighted average of the NRA in Africa obscures a number of significant variations. The African continent can be divided into three regions: resource-rich countries, landlocked countries, and coastal countries. Bates and Block's analysis of agricultural trade intervention makes a number of important observations in this regard. African governments, with the exception of those in landlocked countries, have tended to protect food crops, raising the level of domestic prices above those prevailing in world markets, while taxing cash crops. The distortions introduced by government policies have eroded over time, with nominal rates of assistance for cash crops converging toward zero. Within the region, governments of resource-rich countries tend to provide the most favorable policy environment for producers of both food and cash crops, while the governments of landlocked countries tend to impose the least (Bates and Block 2010).

The major reductions in taxation of farmers have been in such countries as Ghana, Uganda, Tanzania, Cameroon, Senegal and Madagascar, while in Mozambique, and to a lesser extent Kenya, there has been a transition from taxing to supporting farmers. The opposite transition, from slight support to slight taxation, has occurred in Nigeria, while the degree of taxation is still heavy in Cote d'Ivoire, Zambia and Zimbabwe (Anderson and Masters 2009).

In the past, many studies have analyzed the relationship between agricultural protection or taxation and economic development. A common understanding is the change in the political environment accompanying economic development. In the early stage of economic development the government is required to tax agriculture, 


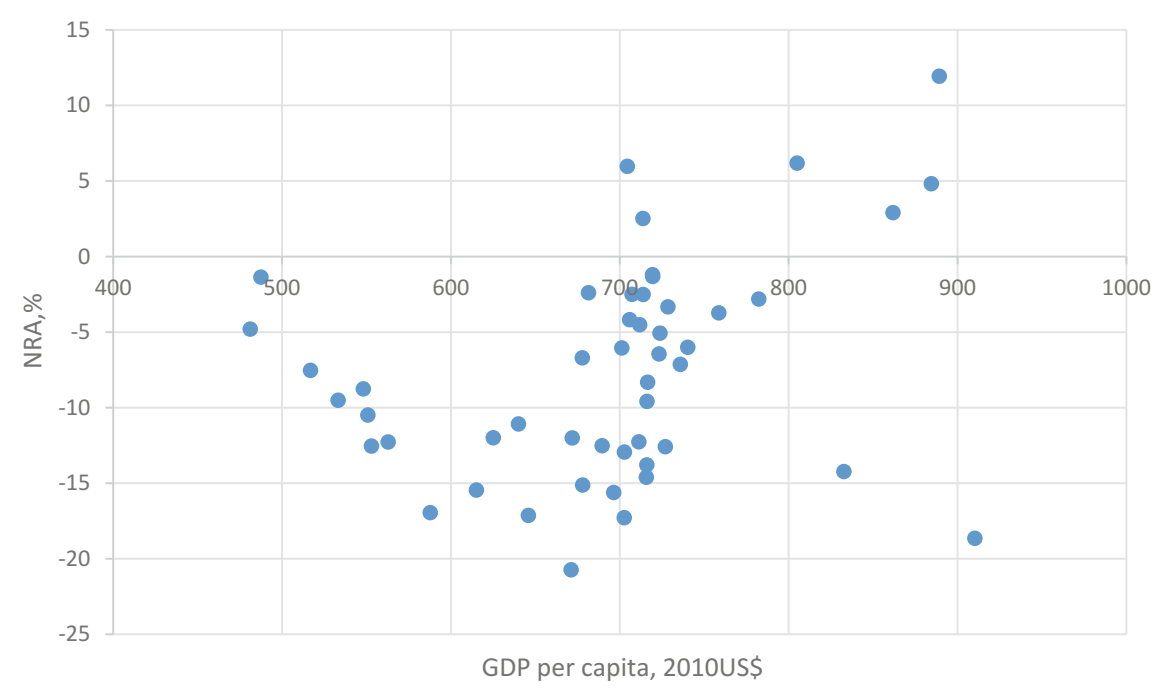

Fig. 11.3 Rerationship between GDP per capita and NRA in Africa, 1961-2010. Source World Bank, National and Global Estimates of Distortions to Agricultural Incentives 1955-2011

which is the largest industry in the economy. Also, in promoting industrialization, it is desirable to keep wages and food prices low. Food prices are an important factor determining wages in the early stage of development with a high Engel coefficient.

Figure 11.3 shows the relationship between the NRA and GDP per capita in Africa. Although it is not very clear, a positive correlation can be observed as a tendency. In Africa, as economic development progresses, the level of agricultural taxation moderates, and it seems that there is a tendency towards agricultural protection.

Another variable representing the change in the political environment accompanying economic development is the political power of the agricultural sector. Many workers are farmers in the early stages of development, but because farmers are scattered throughout the country, a free-rider problem arises (Olson 1965). According to the theory of collective action, it is difficult for farmers to lobby for favorable policy outcomes in agriculture. They have no political power to challenge the government's tax policy. However, as the number of farmers declines as economy develops, lobbying against agricultural taxation can be conducted more efficiently, and if their number declines further, farmers succeed in introducing protection policies.

Figure 11.4 shows how this hypothesis is applied to Africa. The NRA is compared with the political power of agriculture in terms of the share of rural population in the total population. In this case, a negative correlation is observed between the NRA and the rural population share. It shows that the degree of agricultural taxation weakens as the share of rural population decreases, that is, as economic development progresses, and agricultural taxation tends to turn into agricultural protection over the long term. As a determinant of agricultural policies the share of rural population seems to work. 


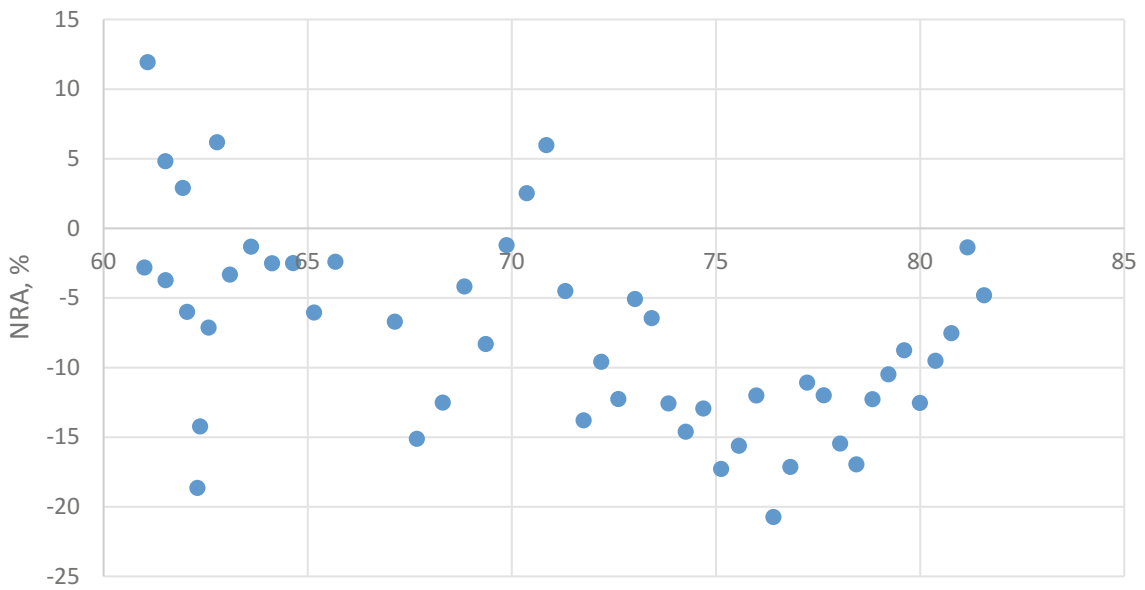

Rural population share, $\%$

Fig. 11.4 Relationship between rural population share and NRA in Africa, 1961-2010. Source World Bank, National and Global Estimates of Distortions to Agricultural Incentives 1955-2011

However, GDP per capita or rural population share alone is not the sole determinant of agricultural policies, which depend on many other factors. Moreover, the numerical value of the NRA shown here is a weighted average that summarizes Africa as a whole in a single index. It is reasonable to consider that many different trends in different countries are hidden in the single NRA and unique characteristics by country may offset each other. Therefore, more detailed analysis is required.

Now, we focus on individual countries in Africa. Table 11.1 shows the average GDP per capita and NRA for agriculture for 20 Sub-Saharan Africa countries in the two periods of 1975-79 and 2006-10 (years varied by country) with the annual growth rate between the two periods. Excluding South Africa, GDP per capita in these countries is in the 200-600 dollar range in 2000 US dollars in the recent years. Although this is still at a low level, many countries grew from the late 1970s with a positive growth rate between the two periods. Six of 20 countries show annual growth rates exceeding 1\%. Ethiopia, Mozambique and Uganda had a high growth rate of $1.72,2.89$, and $2.65 \%$, respectively.

On the other hand, the NRAs for agriculture show many countries' negative values in the 2000s, indicating that agricultural taxation policies prevailed. Only five countries-Chad, Mozambique, Nigeria, South Africa and Sudan-had a positive NRA. However, looking at the annual rate of increase in the NRA between the two periods, 13 out of the 20 countries show positive values. This means that the degree of agricultural taxation declined, and some countries switched from taxing to protecting agriculture.

In the 1975-79 period, 11 countries had an NRA of minus $10 \%$ or less. Seven of the 11 are in coastal regions. Most of the coastal countries exported agricultural products on which governments imposed export tax. However, this trend in the NRA 
Table 11.1 NRA and GDP per capita in 20 African countries

\begin{tabular}{|c|c|c|c|}
\hline County (Region ${ }^{\mathrm{a}}$ ) & Period & GDP per capitab & NRA $(\%)^{\mathrm{c}}$ \\
\hline \multirow[t]{3}{*}{$\operatorname{Benin}(\mathrm{C})$} & $1975-79$ & 276 & -0.50 \\
\hline & $2001-05$ & 321 & -0.12 \\
\hline & Growth rate & 0.58 & 0.01 \\
\hline \multirow[t]{3}{*}{ Burkina Faso (L) } & $1975-79$ & 159 & -1.51 \\
\hline & 2006-10 & 263 & -7.19 \\
\hline & Growth rate & 1.64 & -0.18 \\
\hline \multirow[t]{3}{*}{ Cameroon (R, C) } & $1975-79$ & 638 & -14.35 \\
\hline & 2005-09 & 695 & -1.67 \\
\hline & Growth rate & 0.29 & 0.42 \\
\hline \multirow[t]{3}{*}{ Chad (L) } & $1975-79$ & 197 & -4.70 \\
\hline & $2001-05$ & 220 & 0.13 \\
\hline & Growth rate & 0.42 & 0.19 \\
\hline \multirow[t]{3}{*}{ Cote d'ivoire (C) } & $1975-79$ & 1051 & -34.71 \\
\hline & 2005-09 & 565 & -29.74 \\
\hline & Growth rate & -2.05 & 0.17 \\
\hline \multirow[t]{3}{*}{ Ethiopia (L) } & $1981-85$ & 123 & -18.69 \\
\hline & $2006-10$ & 188 & -4.65 \\
\hline & Growth rate & 1.72 & 0.56 \\
\hline \multirow[t]{3}{*}{ Ghana $(\mathrm{C})$} & 1975-79 & 238 & -25.58 \\
\hline & $2006-10$ & 328 & -3.91 \\
\hline & Growth rate & 1.03 & 0.70 \\
\hline \multirow[t]{3}{*}{ Kenya (C) } & $1975-79$ & 402 & -1.66 \\
\hline & $2006-10$ & 455 & -1.20 \\
\hline & Growth rate & 0.41 & 0.01 \\
\hline \multirow[t]{3}{*}{ Madagascar (C) } & $1975-79$ & 346 & -27.06 \\
\hline & $2006-10$ & 248 & -2.37 \\
\hline & Growth rate & -1.08 & 0.80 \\
\hline \multirow[t]{3}{*}{ Mali (L) } & $1975-79$ & 251 & -2.18 \\
\hline & 2006-10 & 276 & -4.52 \\
\hline & Growth rate & 0.31 & -0.08 \\
\hline \multirow[t]{3}{*}{ Mozambique (C) } & $1981-85$ & 176 & -29.74 \\
\hline & $2006-10$ & 359 & 7.33 \\
\hline & Growth rate & 2.89 & 1.48 \\
\hline \multirow[t]{3}{*}{ Nigeria $(\mathrm{R}, \mathrm{C})$} & $1975-79$ & 439 & 6.34 \\
\hline & $2006-10$ & 492 & 1.85 \\
\hline & Growth rate & 0.37 & -0.14 \\
\hline
\end{tabular}


Table 11.1 (continued)

\begin{tabular}{|c|c|c|c|}
\hline County (Region ${ }^{\mathrm{a}}$ ) & Period & GDP per capita ${ }^{b}$ & $\operatorname{NRA}(\%)^{\mathrm{c}}$ \\
\hline \multirow[t]{3}{*}{ Senegal (C) } & $1975-79$ & 495 & -22.74 \\
\hline & $2001-05$ & 475 & -1.11 \\
\hline & Growth rate & -0.16 & 0.83 \\
\hline \multirow[t]{3}{*}{ South Africa $(\mathrm{R}, \mathrm{C})$} & $1975-79$ & 3296 & 3.83 \\
\hline & $2006-10$ & 3702 & 2.38 \\
\hline & Growth rate & 0.38 & -0.05 \\
\hline \multirow[t]{3}{*}{ Sudan (L) } & $1975-79$ & 313 & -24.33 \\
\hline & $2006-10$ & 515 & 0.77 \\
\hline & Growth rate & 1.62 & 0.81 \\
\hline \multirow[t]{3}{*}{ Tanzania (C) } & $1976-80$ & n.a. & -44.80 \\
\hline & $2006-10$ & 402 & -1.58 \\
\hline & Growth rate & n.a. & 1.73 \\
\hline \multirow[t]{3}{*}{ Togo (C) } & $1975-79$ & 314 & -0.40 \\
\hline & $2006-10$ & 265 & -4.24 \\
\hline & Growth rate & -0.55 & -0.12 \\
\hline \multirow[t]{3}{*}{ Uganda (L) } & $1981-85$ & 173 & -6.79 \\
\hline & 2006-10 & 332 & -15.83 \\
\hline & Growth rate & 2.65 & -0.36 \\
\hline \multirow[t]{3}{*}{ Zambia (R, L) } & $1975-79$ & 506 & -37.29 \\
\hline & 2001-05 & 335 & -14.02 \\
\hline & Growth rate & -1.57 & 0.89 \\
\hline \multirow[t]{3}{*}{ Zimbabwe (L) } & $1975-79$ & 594 & -28.60 \\
\hline & $2001-05$ & 492 & -37.96 \\
\hline & Growth rate & -0.72 & -0.36 \\
\hline
\end{tabular}

Source World Bank, National and Global Estimates of Distortions to Agricultural Incentives 1955-2011

Note

${ }^{\text {a }}$ Region is classified as follows: $\mathrm{C}$ is coastal, $\mathrm{L}$ is landlocked, and $\mathrm{R}$ is resource-rich

${ }^{\mathrm{b}} \mathrm{GDP}$ per capita is in 2000 US dollars and growth rate is annual compounded gwowth rate between the two periods

${ }^{\mathrm{c}}$ Growth rate of the NRA is the annual average of increases between the two periods

diminished by the 2000s. Coastal countries are just one of four that show a nominal rate of protection (NRP) of minus $10 \%$ or less in the 2000s. It is notable that coastal countries show larger increases in the NRA per year during the two periods than other regions; eight of 13 countries that have a positive annual increase rate are coastal countries. In other words, distortions by market intervention in agriculture have been corrected in coastal countries, which were subject to agricultural taxation.

African countries have adopted policies to tax agriculture for a long time, which contributed to state finances and kept food prices low, thereby preventing wage 
rises. However, in recent years the agricultural taxation trend weakened and the price distortion was corrected to some degree. Furthermore, as seen from the Asian experience of emerging economies, the income disparity between agriculture and industry tends to expand and become a social and economic problem in some African countries. Agricultural policy has to deal with that problem.

\subsection{The Relationship Between Economic Development and Agricultural Protection Policy}

A formal model showing the relationship between the NRA and economic development is presented in this section. First, it is assumed that politicians (or political parties) seek to maximize votes in elections.

The level of protection (taxation) desirable for politicians is, therefore, the level that maximizes their political power by maximizing the number of votes in elections. Even those who benefit from a policy or those who suffer losses express their intention by voting. Thus, it is necessary to examine the relationship between the costs and benefits for politicians who set the level of agricultural protection.

Politicians calculate how many votes they will secure by raising the level of agricultural protection. These votes will be cast by farmers. On the other hand, they also have to calculate how many votes will be lost by choosing the same policy. Those who previously supported the politicians may change their minds and not vote for them if they do not like an increase in the level of agricultural protection. They are most likely consumers.

Politicians calculate votes earned and votes lost in order to maximize their total vote. Maximizing votes then becomes a matter of setting the agricultural protection level at the point where the marginal benefit coincides with the marginal cost of the policy. The marginal benefit is an increment in the votes gained by increasing a unit of agricultural protection level while the marginal cost is a decrement of votes lost by the same policy.

Figure 11.5 shows the marginal benefit curve (MB) and the marginal cost curve (MC), which change along the level of agricultural protection. MB is described as a line with a downward slope to the right because the marginal utility (gain) of farmers declines as the level of protection is raised. On the other hand, MC is a line with an upward slope to the right because the marginal dis-utility (pain) of consumers increases as food prices are raised. Politicians can maximize votes by setting the protection level at $\mathrm{T}$ at which point $\mathrm{MB}$ and $\mathrm{MC}$ are intersected shown at point $\mathrm{E}$.

While the level of protection desirable for politicians is not necessarily the socially desirable level of protection, it is not easy to break this equilibrium because the determination of the protection level is built into the structure of politics. Market failure can be caused by monopolies, the provision of public goods, the existence of externalities and information asymmetries, but not only the market but also governments and politics can fail. 


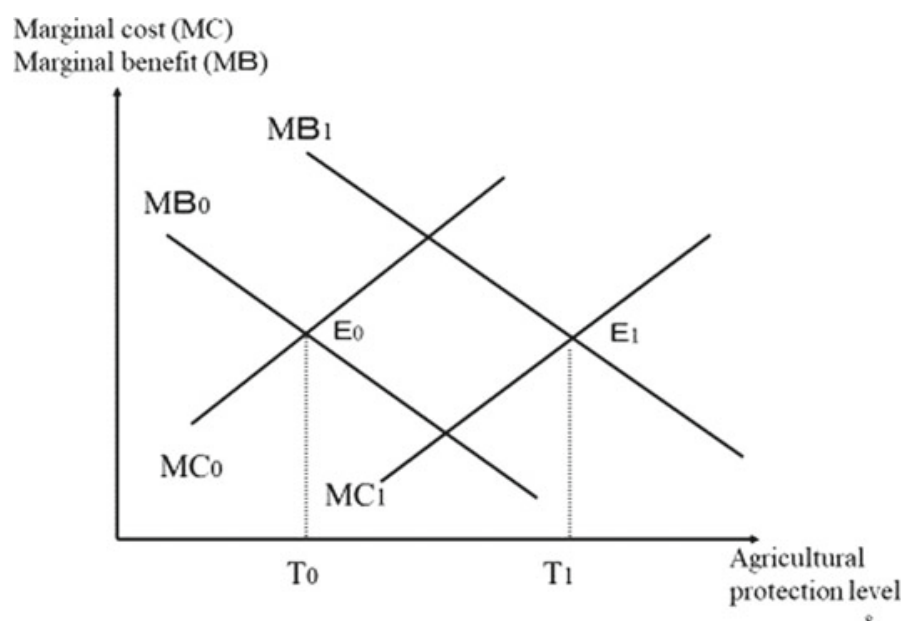

Fig. 11.5 Political determination of agricultural protection level

In the early stages of economic development, many farmers benefit from agricultural protection, but there is no organizational capacity or ability to make politicians increase their supporting votes. The proportion of the products for market sale is small so that there are few incentives to ask for price support. For politicians, the increment in support obtained from agricultural protection policy is small and therefore the marginal benefit curve is low. On the other hand, political pressures from industrial sector leaders who oppose agricultural protection are strong and well organized. Also, as agricultural price rises put pressure on the lives of urban workers and even cause riots, there are a large number of potential votes lost by increasing the level of agricultural protection. That is, the marginal cost curve for agricultural protection is set high. As a result, the level of agricultural protection in developing countries is extremely low, and in some cases, there is a negative protection level. Even agricultural deprivation measures are introduced.

However, as economic development progresses, the political environment also changes. First, as commercialization of agricultural products progresses, farmers' income becomes more dependent on prices of agricultural products because they sell the products in the market. The educational level of farmers also increases, and as transportation and communications develop, farmers become conscious of the gap in the standard of living between urban and rural areas, which expands in the process of industrialization. Therefore, farmers have greater desire for agricultural protection than before.

Voices calling for protection of agriculture are united through agencies such as agricultural organizations and become political pressures. As the industrial sector expands, the agricultural sector shrinks and the number of farmers also decreases, but in reality, this phenomenon itself increases the farmers' political power. When a group collectively tries to do something for a purpose, the smaller the members of 
that group, the higher the participation rate in that action and therefore the higher the efficiency. The reason is that if the number of people is large, the role of an individual is small, and there is a tendency to think that they have no influence on the whole. But if the group is smaller, this free rider problem can be prevented. This is what Olson pointed out in Theory of Collective Action (Olson 1965).

In this way, farmers' groups, which become more efficient at lobbying as the economy develops, can promise politicians to gain larger numbers of supporting votes in exchange for stronger agricultural protection. Also, fertilizer and other agricultural input material industries that depend on agricultural production support agricultural protection. Therefore, as the economy develops, the marginal benefit curve to politicians for supplying agricultural protection shifts higher upwards.

How about opposition to agricultural protection? As per capita income increases with economic development, the proportion of food expenses in total consumption declines. Rising grocery prices do not have as much impact on workers' lives as before, and their resistance to agricultural protection diminishes. Also, since the industrial structure itself shifts from labor-intensive to capital-intensive, the importance of wages is small for management and capitalists. Thus, their consciousness of prices of agricultural products diminishes. Furthermore, as the non-agricultural sector expands, the number of enterprises also increases, and even if they try to act jointly, the free rider phenomenon described above occurs and cooperation cannot be achieved at previous levels.

Most people engage in non-agricultural sectors in the developed-country stage. The cost of protecting agriculture is very small for non-agricultural people on a per capita basis. The costs necessary to provide the same protection to the small number of farmers drop drastically so resistance is reduced accordingly. In addition, at this stage, the importance of the non-economic value of agriculture such as conservation of green space and maintenance of country scenery in rural areas is increasingly asserted. Thus, protection of agriculture tends to be easy to accept. These changes shift the marginal cost curve of agricultural protection for politicians downwards.

For politicians, the marginal benefits from agricultural protection are strengthened and the marginal costs are reduced, resulting in both MR and MC curves shifting to the right and agricultural protection levels at the developed-country stage rising.

\subsection{Determinants of the Agricultural Protection Level}

This section presents a mechanism to determine the agricultural protection level based on the above model. An important variable that directly affects the number of votes cast for a politician in terms of agricultural protection policy is the relative farm household income in comparison with workers' income of the industrial sector. The income disparity between the agricultural and industrial sectors is neglected in the early stages of development. But, as development progresses, remediation of income disparity becomes a policy issue. 
The labor wage rate is used as the most important variable representing income. The demand curve for labor is derived as marginal labor productivity: that is, the physical marginal labor productivity multiplied by the product price. The wage rate is determined at the level where the labor demand curve intersects with the labor supply curve. If the labor market is competitive, the wage rate is the same in agriculture and industry. However, production resources invested in the agricultural sector are mostly specific to agriculture and the migration and shifting of agricultural resources to the industrial sector are difficult and impose a large transaction cost including psychological costs. Therefore, the wage rate is determined differently between agriculture and industry equalizing it to the marginal value productivity of labor in each sector as follows:

$$
\begin{aligned}
\mathrm{Wa} & =\mathrm{Pa} \mathrm{MLa} \\
\mathrm{Wm} & =\mathrm{Pm} \text { MLm }
\end{aligned}
$$

where $\mathrm{Wa}$ and $\mathrm{Wm}$ are the agricultural and industrial wage rates, respectively. $\mathrm{Pa}$ and Pm are the price of agricultural and industrial products, respectively. MLa and MLm represent the physical marginal productivity of agricultural and industrial labor, respectively.

As economic development progresses, the income disparity between the agricultural and industrial sectors expands, and it becomes a policy issue to keep this gap at a certain level. Therefore, in order to balance the wage rate in agriculture with that in industrial sector at a certain level politically, the following relationship must be satisfied.

$$
\mathrm{Wa}^{*}=\mathrm{k} \mathrm{Wm}
$$

where $\mathrm{Wa}^{*}$ is a politically desirable level of the wage rate in agriculture and $\mathrm{k}$ is a parameter indicating how much the government intends to rectify the income disparity. Politicians expect to increase the number of votes cast by strengthening the protection of agriculture, namely raising $\mathrm{k}$, while it decreases the number of votes cast by groups who oppose agricultural protection such as consumer groups. The value of $\mathrm{k}$ is determined so as to equalize the marginal benefit and the marginal cost for politicians.

The marginal benefit curve, MB, shifts upward because of the strengthening political power of the agricultural sector as the economy develops. The share of rural population in total population (SA) is an indicator that shows the political power of the agricultural sector. On the other hand, the marginal cost curve, MC, shifts downward owing to the rising social tolerance of agricultural protection. As an indicator of the marginal cost, GDP divided by rural population (GA) is used. The variable GA needs to be explained as follows.

The marginal cost of increasing the level of agricultural protection for politicians is the marginal loss of votes from consumers. As income goes up, consumers tend not to be conscious of food prices because the Engel coefficient decreases. Also, if the 
share of farmers in total population declines, the total cost of protecting agriculture is reduced. Thus, consumers' tolerance of agricultural protection is a function of GDP per capita and the share of farmers who are protected. The variable GA is introduced as a proxy to indicate consumers' tolerance, which is GDP per rural population calculated by GDP per capita (GDP/N) multiplied by the reciprocal of the share of rural population in total population $(\mathrm{N} / \mathrm{Na})$, where $\mathrm{N}$ is total population and $\mathrm{Na}$ is rural population.

Then, MR and MC are expressed as follows.

$$
\begin{aligned}
\mathrm{MB} & =\mathrm{f}(\mathrm{k}, \mathrm{SA}) \\
\mathrm{MC} & =\mathrm{g}(\mathrm{k}, \mathrm{GA})
\end{aligned}
$$

Since the value of $\mathrm{k}$ is determined at the point where MB and MC are equalized in equilibrium, $\mathrm{k}$ is expressed by the exogenous variables $\mathrm{SA}$ and GA.

$$
\mathrm{k}=\mathrm{k}(\mathrm{SA}, \mathrm{GA})
$$

The domestic price is the international price PW multiplied by the nominal protection coefficient (NPC), which is the nominal rate of protection (NRP, the difference between domestic and foreign prices divided by foreign price) plus 1 . Therefore, Eq. (11.1) becomes as follows.

$$
\mathrm{Wa}=\text { NPC PWa MLa }
$$

If the NRP is politically manipulated by politicians who try to correct the income disparity between the agricultural and industrial sectors, the nominal protection coefficient of the domestic agricultural products can be expressed as follows, using Eqs. (11.2), (11.3), (11.6) and (11.7).

$$
\mathrm{NPC}=\mathrm{NRP}+1=\mathrm{k}(\mathrm{SA}, \mathrm{GA})\left(\frac{\mathrm{PWa}}{\mathrm{Pm}}\right)^{-1}\left(\frac{\mathrm{MLa}}{\mathrm{MLm}}\right)^{-1}
$$

The level of agricultural protection depends on the share of rural population (SA), the GDP per capita of rural population (GA), the terms of trade of agricultural products to industrial products in international trade $(\mathrm{PWa} / \mathrm{Pm})$, assuming no distortions in industrial sector, and the marginal productivity ratio of the agricultural sector to the industrial sector (MLa/MLm).

An important fact is that as long as the marginal labor productivity gap between agriculture and industry is expanding, the level of agricultural protection needs to continue to rise to correct it. If economic growth accompanies industrialization and productivity in industrial sector continues to rise, agricultural protection will continue to be strengthened. In other words, even if the agricultural protection level is kept high, the political objective cannot be achieved unless the protection level is raised continuously. Agricultural protection has to grow under this mechanism. 


\subsection{Regression Analysis of Agricultural Protection Level}

Based on Eq. (11.8), a regression analysis is conducted using pool data of 20 SubSahara African countries for 1961-2010. Countries in the sample are Benin, Burkina Faso, Cameroon, Chad, Cote d'Ivoire, Ethiopia, Ghana, Kenya, Madagascar, Mali, Mozambique, Nigeria, Senegal, South Africa, Sudan, Tanzania, Togo, Uganda, Zambia, and Zimbabwe. The number of years for which data are available is different by country.

Data for the NRP used in the dependent variable are nra_tott (NRA, all primary agriculture, total for covered and non-covered) from the series of World Bank's National and Global Estimates of Distortions to Agricultural Incentives, 1955-2011. The data include domestic subsidies as well as the value of differences between the domestic and international prices of the products. For the country level of protection, a weighted average of the NRA of individual agricultural products is calculated with weights of gross values of production at unassisted prices.

Data used for the explanatory variables are as follows. The share of rural population to total population (SA) and the GDP per capita of rural population (GA) are available in the World Development Indicators of the World Bank, where GDP is expressed in 2010 constant US dollars. For the variable of the terms of trade (PA = $\mathrm{PWa} / \mathrm{Pm}$ ), data of the import price (unit value) index of agricultural products for each country are used for PWa while date of the export price (unit price) index of Africa as a whole are used for Pm. Data are available in the Trade Indices of the United Nations. For the variable of the marginal productivity ratio of the agricultural sector to the industrial sector $(\mathrm{LA}=\mathrm{MLa} / \mathrm{MLm})$, the ratio of average labor productivity in agriculture to that in the non-agricultural sector is used because data for marginal labor productivity are not available. The labor productivity of agriculture is derived from the added value of the agricultural sector divided by rural population while the labor productivity of the non-agricultural sector is derived from the non-agricultural GDP divided by the non-rural population. Data are available in the World Development Indicators of the World Bank, where GDP is expressed in 2010 constant US dollars.

The equation for estimation is expressed as follows:

$$
\begin{aligned}
\ln (1+N R A i t)= & \beta 0+\beta 1 \ln \text { SAit } \\
& +\beta 2 \ln \text { GAit }+\beta 3 \ln L A i t+\beta 4 \ln \text { PAit }+\gamma i+\varepsilon i t
\end{aligned}
$$

where $i$ is a subscript that represents a country, $t$ is a subscript that represents a year, $\gamma i$ indicates the fixed effect of a country unchanged with respect to time, and $\varepsilon$ it is an error term. The expected signs of the coefficients are $\beta 1<0, \beta 2>0, \beta 3<0$ and $\beta 4<0$.

The results of the regression analysis using the fixed effect model are summarized in Table 11.2. First, looking at the relationship between rural population share and agricultural protection level in estimation (1), it is found that there is a statistically significant relationship between them. The correlation was not clear in Fig. 11.1, 
Table 11.2 Results of regressions of nominal protection coefficient (NPC) in Africa

\begin{tabular}{l|l|l|l|l}
\hline & $(1)$ & $(2)$ & $(3)$ & $(4)$ \\
\hline Rural pop share & $-0.2508 * * *$ & $-0.3757 * * *$ & $-0.2793 * * *$ & $-0.3204 * * *$ \\
\hline $\ln (\mathrm{SA})$ & $(0.0500)$ & $(0.0731)$ & $(0.0957)$ & $(0.0200)$ \\
\hline GDP per rural pop & & & 0.0566 & $0.0115 * *$ \\
\hline $\ln (\mathrm{GA})$ & & & $(0.0351)$ & $(0.0072)$ \\
\hline Labor productivity ratio & & $-0.0451 * *$ & $-0.0351 *$ & $-0.0398 * * *$ \\
\hline $\ln (\mathrm{LA})$ & & $(0.0194)$ & $(0.0205)$ & $(0.0040)$ \\
\hline Relative price & & & & $-0.0324 * * *$ \\
\hline $\ln (\mathrm{PA})$ & & & & $(0.0035)$ \\
\hline Constant & $-0.1045 * * *$ & $-0.2189 * * *$ & $-0.5105 * * *$ & $-0.2549 * * *$ \\
\cline { 2 - 5 } & $(0.0330)$ & $(0.0572)$ & $(0.1909)$ & $(0.0399)$ \\
\hline Observations & 869 & 745 & 735 & 655 \\
\hline Adjusted $\mathrm{R}^{2}$ & 0.440 & 0.428 & 0.427 & 0.511 \\
\hline
\end{tabular}

Source Author's calculation

Note Standard errors in parentheses

*Significant at $10 \%$; * significant at $5 \%$; ***significant at $1 \%$

which showed the relationship between the share of rural population and the NRA in a weighted average for Africa as a whole. But the regression result in the country fixed-effect model here confirms a negative relationship between them.

Next, in estimation (2), the variable of the labor productivity ratio is added to the rural population share. The coefficient of this variable is also statistically significant as well as that of the rural population share. It shows that if labor productivity in the agricultural sector falls behind the nonagricultural sector, the level of agricultural protection rises. Thus, the hypothesis of the political correction of income disparity in the course of economic development is proven.

Furthermore, in estimation (3), which adds another political variable-GDP per capita of rural population-the coefficient takes a positive value as expected, but it is not statistically significant. This variable indicates whether the people are vital to protecting agriculture or not, but it could not be confirmed in Africa.

Finally, the relative price variable is added in estimation (4), which includes all the variables of the model presented in the previous section. The number of observations used for estimation is reduced because countries and years for which relative prices cannot be obtained are excluded. In the estimation of the full model, all the coefficients show signs as expected, and are statistically significant except for the GDP per capita of rural population variable.

The result of the full model estimation (4) confirms the relationship between the agricultural protection level and political and economic factors is relevant to politicians' behavior in seeking to maximize votes. In African countries, if the rural population share decreases by $1 \%$, it may cause $0.32 \%$ increases in the agricultural protection level. That is, taxation on agriculture is reduced in the course of economic 
development. If the GDP per capita of the rural population increases by $1 \%$, the protection level may increase by $0.1 \%$. However, this relationship is not statistically significant. In other words, if other conditions are kept constant, it can be argued that in Africa the economy is not growing sufficiently to become tolerant of agricultural protection. In other words, African consumers and governments have changed the level of agricultural taxation for other reasons.

An important variable in relation to economic development is the relative labor productivity of agriculture. The source of economic development is often the growth in the industrial sector. The rapid growth of the industrial sector expands the disparity in labor productivity between agriculture and industry, resulting in income disparity. Although the value of the coefficient is small, the estimation result shows that the expansion in this productivity gap lowered agricultural taxation and, as seen in recent years, it turned into agricultural protection.

The variable of the relative price is also statistically significant, indicating that if the terms of trade become disadvantageous to agriculture, the agricultural protection level rises slightly but clearly. However, in this estimation, the price of the industrial sector is represented by Africa's total export unit value index. An analysis with data showing more accurate terms of trade would be desirable.

There are a number of residual problems in the statistical estimations. First, the independent variables of the estimated equations are not mutually independent. The share of rural population, GDP per capita of rural population, and relative labor productivity are all indicators that show economic development and are related to each other. Therefore, a problem of multiple-collinearity may be involved. Changes in agricultural protection levels also affect the relative labor productivity of agriculture and even the rural population share. Therefore, the estimated results here may contain a simultaneous equation bias.

In the future, it would be desirable to analyze the levels of agricultural protection in a general equilibrium framework together with growth in the non-agricultural sector.

\subsection{Conclusion}

Research on agricultural protection has been very active and many studies have contributed to clarification of the determinants of protection. Also, construction of statistical data sets including those of the World Bank made possible consistent comparisons of levels agricultural protection and distortions internationally. This chapter has benefited from the availability of data on agricultural protection levels and has used the data to test the hypothesis called the "developmental paradox" in Africa. A model to describe the "developmental paradox" has been proposed and tested by statistical estimations.

Rapid economic development makes the agricultural sector shrink, which may cause social and economic disorder in rural areas. It also becomes a factor encouraging political unrest. Therefore, agricultural protection policies tend to be adopted 
for the purpose of correcting income disparities between agriculture and industry. Indeed, the "developmental paradox" has been observed in Japan, Korea and Taiwan during their rapid economic growth period (Honma and Hayami 1986, 2009).

It is somewhat challenging to apply this model to Africa where economic development is still underway. However, the logic of reducing taxation on agriculture is the same as increasing agricultural protection. Further, it is meaningful to extract common factors that determine agricultural policies taking into account the differences in individual countries in a fixed effect model in Africa.

The "developmental paradox" is an empirical question and should be tested for those countries that are in the course of economic development such as in Africa. It is based on the behavior of politicians seeking to maximize votes. However, because of over-simplification, more complicated political and economic behaviors such as opposition parties' actions and policy struggles are neglected in the model. Despite the over-simplification, the statistical tests confirmed the significance of variables derived from the model, which show common factors that determine the level of agricultural protection among countries in Sub-Saharan Africa: the share of rural population, GDP per capita of rural population, relative labor productivity, and the terms of trade in international markets.

The government plays a major role in economic development. This chapter has shown that agricultural taxation policy declines as economic development progresses and that even African countries have adopted agricultural protection policies. Africa's economic development may have been more advanced if agricultural taxation had been eliminated earlier. If emerging countries in Africa had focused on improving infrastructure such as irrigation and drainage facilities and on investing in road and transportation rather than on taxing agriculture in the early stage of development, they might have been able to achieve agriculture-based growth faster.

Today many African countries still continue to impose agricultural taxes which need to be eliminated as soon as possible. In addition, emerging countries in Africa where further economic growth is expected in the future should not follow the experience of emerging Asian countries, which mistakenly introduced agricultural protection as an industrial adjustment policy to correct income disparity. Avoiding market intervention and correcting distortions of farmer's incentives are necessary even if correcting income disparity is a political priority in Africa. So-called decoupled policies such as direct payments with public investment in agricultural infrastructure should be introduced to promote agricultural growth. 


\section{References}

Acemoglu, D., Johnson, S., \& Robinson, J. A. (2001). The colonial origins of comparative development: An empirical investigation. American Economic Review, 91(5), 1369-1401.

Anderson, K. (Ed.). (2009). Distortions to agricultural incentives: A global perspective, 1955-2007. London/Washington, DC: Palgrave Macmillan/World Bank.

Anderson, K., Hayami, Y., et al. (1986). The political economy of agricultural protection: East Asia in international perspective. London and Boston: Allen and Unwin.

Anderson, K., \& Masters, W. (Eds.). (2009). Distortions to agricultural incentives in Africa. Washington, DC: World Bank.

Bates, R. H. (1989). Beyond the miracle of the market: The political economy of agrarian development in Rural Kenya. Cambridge and New York: Cambridge University Press.

Bates, R. H., \& Block, S. (2010). Agricultural trade interventions in Africa (Chap. 12). In K. Anderson (Ed.), The political economy of agricultural price distortions. New York: Cambridge University Press.

Block, S., \& Bates, R. H. (2011). Political institutions and agricultural trade interventions in Africa. American Journal of Agricultural Economics, 93(2), 317-323.

De Gorter, H., \& Swinnen, J. F. M. (2002). Political economy of agricultural policies. In B. Gardner \& G. Rausser (Eds.), The handbook of agricultural economics (Vol. 2). Amsterdam: Elsevier Science.

Gardner, B. L. (1987). Causes of U.S. farm commodity programs. Journal of Political Economy, 95(2), 290-310.

Grossman, G. M., \& Helpman, E. (1994). Protection for sale. American Economic Review, 84(4), $833-850$.

Grossman, G. M., \& Helpman, E. (2002). Interest groups and trade policy. Princeton, NJ: Princeton University Press.

Hoeffler, H. (2011). The political economy of agricultural policies in Africa: History, analytical concepts and implications for development cooperation. Quarterly Journal of International Agriculture, 50(1), 29-53.

Honma, M., \& Hayami, Y. (1986). The determinants of agricultural protection levels: An econometric analysis (Chap. 4). In K. Anderson, Y. Hayami, et al. (Eds.), The political economy of agricultural protection: East Asia in international perspective. London: Allen and Unwin.

Honma, M., \& Hayami, Y. (2009). Japan, Republic Korea, and Taiwan, China (Chap. 2). In K. Anderson (Ed.), Distortions to agricultural incentives: A global perspective, 1955-2007. London/Washington, DC: Palgrave Macmillan/World Bank.

Krueger, A. O., Schiff, M., \& Valdés, A. (1988). Agricultural incentives in developing countries: Measuring the effect of sectoral and economywide policies. World Bank Economic Review, 2(3), $255-272$.

Krueger, A. O., Schiff, M., \& Valdés, A. (1991). The political economy of agricultural pricing policy. London: Johns Hopkins University Press for the World Bank.

Lindert, P. H. (1991). Historical patterns of agricultural policy. In C. Timmer (Ed.), Agriculture and the state: Growth, employment, and poverty. Ithaca, NY: Cornell University Press.

Olson, M. (1965). The logic of collective action. New Haven: Yale University Press.

Persson, T., \& Tabellini, G. E. (2000). Political economics: Explaining economic policy. Cambridge, MA: MIT Press.

Poulton, C. (2014). Democratisation and the political incentives for agricultural policy in Africa. Development Policy Review, 32(S2), s101-s122.

Shleifer, A. (1997). Government in transition. European Economic Review, 41(3-5), 385-410.

Swinnen, J. F. M., Banerjee, A. N., \& De Gorter, H. (2001). Economic development, institutional change, and the political economy of agricultural protection: An econometric study of Belgium since the 19th century. Agricultural Economics, 26(1), 25-43.

Tracy, M. (1989). Government and agriculture in Western Europe 1880-1988 (3rd ed.). New York: Harvester Wheatsheaf. 
Open Access This chapter is licensed under the terms of the Creative Commons AttributionNonCommercial-NoDerivatives 4.0 International License (http://creativecommons.org/licenses/bync-nd/4.0/), which permits any noncommercial use, sharing, distribution and reproduction in any medium or format, as long as you give appropriate credit to the original author(s) and the source, provide a link to the Creative Commons licence and indicate if you modified the licensed material. You do not have permission under this licence to share adapted material derived from this chapter or parts of it.

The images or other third party material in this chapter are included in the chapter's Creative Commons licence, unless indicated otherwise in a credit line to the material. If material is not included in the chapter's Creative Commons licence and your intended use is not permitted by statutory regulation or exceeds the permitted use, you will need to obtain permission directly from the copyright holder.

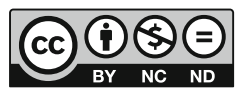

